\title{
Hypomagnesemia in critically ill patients
}

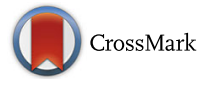

\author{
Bent-Are Hansen ${ }^{1}$ and Øyvind Bruserud ${ }^{2 *}$
}

\begin{abstract}
Background: Magnesium (Mg) is essential for life and plays a crucial role in several biochemical and physiological processes in the human body. Hypomagnesemia is common in all hospitalized patients, especially in critically ill patients with coexisting electrolyte abnormalities. Hypomagnesemia may cause severe and potential fatal complications if not timely diagnosed and properly treated, and associate with increased mortality.

Main body: Mg deficiency in critically ill patients is mainly caused by gastrointestinal and/or renal disorders and may lead to secondary hypokalemia and hypocalcemia, and severe neuromuscular and cardiovascular clinical manifestations. Because of the physical distribution of $\mathrm{Mg}$, there are no readily or easy methods to assess $\mathrm{Mg}$ status. However, serum $\mathrm{Mg}$ and the Mg tolerance test are most widely used. There are limited studies to guide intermittent therapy of Mg deficiency in critically ill patients, but some empirical guidelines exist. Further clinical trials and critical evaluation of empiric Mg replacement strategies is needed.
\end{abstract}

Conclusion: Patients at risk of Mg deficiency, with typical biochemical findings or clinical symptoms of hypomagnesemia, should be considered for treatment even with serum Mg within the normal range.

Keywords: Magnesium, Critical illness, Intensive care unit, Arrhythmia, Potassium, Calcium

\section{Background}

Magnesium $(\mathrm{Mg})$ is essential for life and plays a crucial role in several biochemical and physiological processes in the human body. Hypomagnesemia is common in hospitalized patients (7-11\%) and even more frequent in patients with other coexisting electrolyte abnormalities [1-3] and in critically ill patients [4, 5]. Hypomagnesemia can potentially cause fatal complications including ventricular arrhythmia, coronary artery spasm, and sudden death. It also associates with increased mortality and prolonged hospitalization [6, 7]. The role of $\mathrm{Mg}$ status and therapy in critically ill patients has previously been systematically reviewed elsewhere [8-10]. However, we here present a review article focusing on the $\mathrm{Mg}$ homeostasis and the physiological role of $\mathrm{Mg}$ in humans. We then present the different causes and clinical and biochemical manifestations of hypomagnesemia in critically ill patients and, finally, we discuss $\mathrm{Mg}$ therapy in the intensive care unit (ICU) setting.

\footnotetext{
* Correspondence: oyvind.bruserud@uib.no

${ }^{2}$ Section for Endocrinology, Department of Clinical Science, University of Bergen, Bergen, Norway

Full list of author information is available at the end of the article
}

\section{Magnesium homeostasis}

$\mathrm{Mg}$ is the fourth most abundant cation in the human body and the second most abundant intracellular cation. A healthy human adult have a content of about $25 \mathrm{~g}$ or $1000 \mathrm{mmol} \mathrm{Mg}$ where approximately 60\% stores in bones, $20 \%$ in muscles, $20 \%$ in soft tissues, $0.5 \%$ in erythrocytes, and $0.3 \%$ in serum [11]. About $70 \%$ of the plasma $\mathrm{Mg}$ is ionized or complexed to filterable ions, while $20 \%$ is bound to proteins. Figure 1 gives a general overview of the Mg homeostasis in the human body.

$\mathrm{Mg}$ homeostasis in humans mainly involves the kidneys, the small bowel, and bones [12]. Gastrointestinal absorption and renal excretion are the most important mechanisms for controlling and regulating the $\mathrm{Mg}$ homeostasis. The cellular regulation of $\mathrm{Mg}$ uptake and release occurs slowly, and healthy individuals need to ingest about $0.15-0.2 \mathrm{mmol} / \mathrm{kg} /$ day to contain a normal $\mathrm{Mg}$ status. The intestinal absorption of dietary Mg depends on both intake and body Mg status and occurs via passive and active pathways [13, 14]. Presumably, only ionized $\mathrm{Mg}$ is absorbed. Active transcellular Mg uptake rely on specific $\mathrm{Mg}$ channels located in the large intestines $[14,15]$ including the transient receptor potential melastin (TRPM) 6 and TRPM 7. The passive absorption is driven by a favorable electrochemical gradient and 


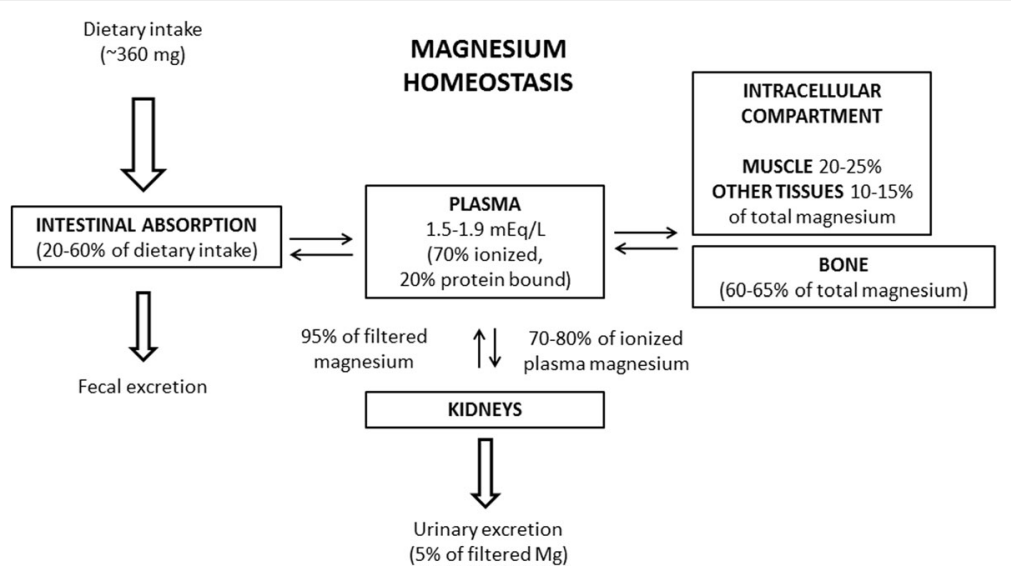

Fig. $1 \mathrm{Mg}$ homeostasis. The figure gives an overview of the Mg homeostasis and the distribution of $\mathrm{Mg}$ throughout the human body including gastrointestinal absorption and renal excretion

occurs mainly paracellulary through leaky epithelia primarily located in the small intestines [14]. Additionally, the process of passive absorption interacts with the levels and absorption of calcium [14].

The kidneys are the primary site of $\mathrm{Mg}$ homeostasis and play a key role in regulating and maintaining $\mathrm{Mg}$ balance. Figure 2 illustrates the renal handling of $\mathrm{Mg}$ in humans. The normal fractional urinary excretion of filtered $\mathrm{Mg}$ is about 5\% [16]. Mg reabsorption in the kidneys involves the proximal tubule, the thick ascending loop of Henle (TAL), and the distal tubule $[17,18]$. TAL is the major site of $\mathrm{Mg}$ reabsorption and reabsorbs about $60-70 \%$ of filtered $\mathrm{Mg}[17,18]$, and extracellular calcium sensing receptors modulate the $\mathrm{Mg}$ absorption through changes in the transepithelial voltage and alterations of the permeability of the paracellular tight junctions [18]. The mechanisms of basolateral transport into the interstitium are not fully understood. Moreover, the proximal tubule reabsorbs $15-20 \%$ of filtered $\mathrm{Mg}$, and the distal tubule only $5-10 \%[17,18]$, whereas there is no significant reabsorption of $\mathrm{Mg}$ in the collecting ducts [19].

\section{Physiological role of magnesium}

$\mathrm{Mg}$ is a crucial cofactor in several enzyme systems [20] including almost every aspect of biochemical metabolism (e.g., DNA and protein synthesis, glycolysis, oxidative phosphorylation). The essential enzymes adenylate cyclase and sodium-potassium-adenosine triphosphatase

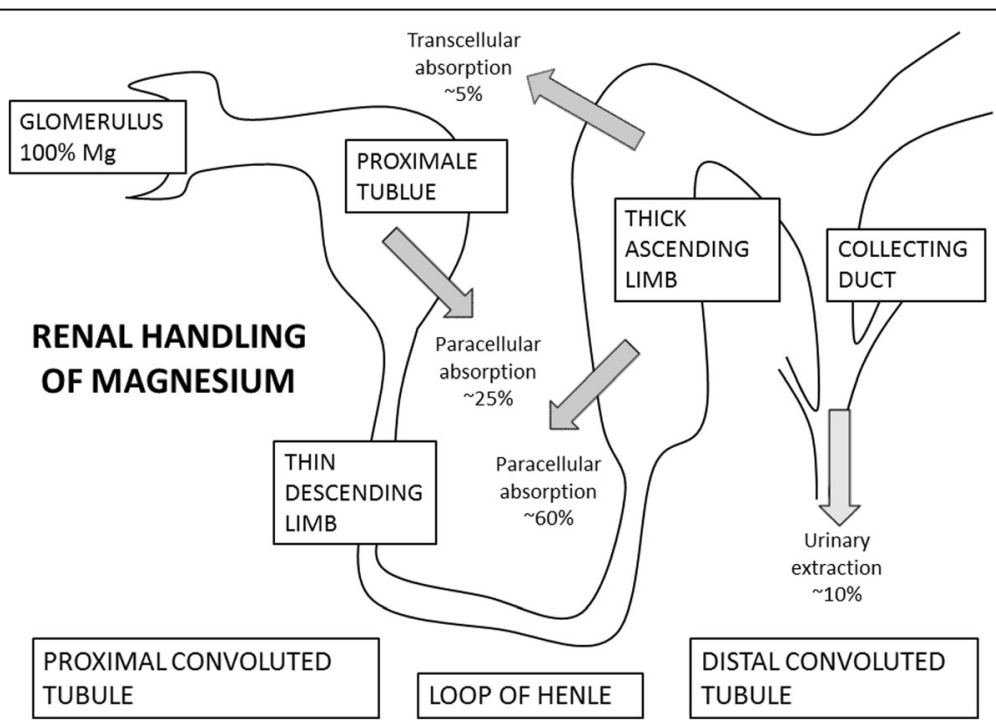

Fig. 2 Renal Mg handling. The figure gives an overview of the renal handling of $\mathrm{Mg}$ in the proximal convoluted tubule, loop of Henle, and distal convoluted tubule 
depend on $\mathrm{Mg}$ for their normal function [21, 22]. $\mathrm{Mg}$ serves as a molecular stabilizer for RNA, DNA, and ribosomes. It is also suggested to modulate immune functions [23, 24], and changes in the level of $\mathrm{Mg}$ are reported to correlate with the levels of several immune mediators such as interleukin-1, tumor necrosis factoralpha, interferon-gamma, and substance P [25-27]. Moreover, $\mathrm{Mg}$ are proven to contribute in several physiological processes such as maintaining stability across cell membranes, protein, and nucleic acid synthesis; regulating cardiac and smooth muscle tone; controlling of mitochondrial functions; and supporting cytoskeletal integrity [28].

\section{Defining magnesium status}

Normal serum concentration of $\mathrm{Mg}$ is 1.5 to $1.9 \mathrm{mEq} / \mathrm{L}$ [29]. Unfortunately, there are no readily and easy methods to assess $\mathrm{Mg}$ status. However, serum $\mathrm{Mg}$ and the $\mathrm{Mg}$ tolerance test are most widely used [30]. The serum $\mathrm{Mg}$ is easily available but may not adequately reflect the body $\mathrm{Mg}$ stores because of the physiological distribution of Mg. Notably, normal serum levels may be found even if a patient is intracellularly $\mathrm{Mg}$ depleted because intracellular stores are recruited to keep the serum levels within its range, however, only until the point where these stores cannot keep up. Although only free $\mathrm{Mg}$ is biologically active, most test measure total $\mathrm{Mg}$ concentrations, and hypoalbuminemic states may therefore lead to false low Mg levels.

The $\mathrm{Mg}$ tolerance test is probably the most accurate way to assess Mg status [31]. The test is used in special occasions for example if the clinical suspicion of $\mathrm{Mg}$ deficiency is strong and the serum $\mathrm{Mg}$ levels are normal. The test is performed by measuring the $\mathrm{Mg}$ in a $24-\mathrm{h}$ urine collection, distribute parenteral $\mathrm{Mg}$ (often $2.4 \mathrm{mg} /$ $\mathrm{kg}$ of lean body weight given over the initial $4 \mathrm{~h}$ of the second urine collection), and then repeat the 24-h urine collection. Patients with a normal Mg status will excrete the Mg load during the second urine collection. Retention of more than 20\% of the administrated $\mathrm{Mg}$ is suggestive of deficiency. Performing the test both gives the diagnosis and treats a potential $\mathrm{Mg}$ deficiency. The $\mathrm{Mg}$ tolerance test could easily be implemented in ICU patients. However, patients with malnutrition, cirrhosis, diarrhea, or long-term diuretic use typically have a positive result and the test is not useful in the setting of renal Mg wasting or other renal dysfunctions.

An alternative to the total serum $\mathrm{Mg}$ and the $\mathrm{Mg}$ tolerance test is assessment of the ionized serum $\mathrm{Mg}^{2+}$ concentration which is the active form of $\mathrm{Mg}$ in plasma [32]. It has a significant protein bound fraction, similar to calcium, with the potential of large differences between total serum and ionized levels [33]. The estimation of ionized $\mathrm{Mg}$ levels in patients cannot be made by correcting for albumin [33]. Notably, it is still disputable whether levels of serum ionized $\mathrm{Mg}$ or total serum $\mathrm{Mg}$ should be used to follow-up Mg levels in critically ill patients [7, 33-40]. Finally, the intracellular levels of $\mathrm{Mg}$ can be measured using circulating red blood cells, mononuclear cells, or skeletal muscle cells. Due to the lack of an accurate and robust method to measure $\mathrm{Mg}$ status in patients, the biochemical measurements should always be supported by a clinical assessment of patients at risk for $\mathrm{Mg}$ deficiency for timely and proper diagnosis and treatment.

\section{Causes of hypomagnesemia in critically ill patients}

The causes of hypomagnesemia in critically ill patients are mainly a result of gastrointestinal disorders or renal loss of Mg. Table 1 lists the differential diagnosis of $\mathrm{Mg}$ deficiency in the ICU patients.

\section{Gastrointestinal causes}

Both the upper and lower intestinal tract fluid contain $\mathrm{Mg}$. Therefore, loss of gastrointestinal fluids can cause $\mathrm{Mg}$ deficiency. Several conditions commonly seen in the ICU patients can cause gastrointestinal loss of $\mathrm{Mg}$ leading to

Table 1 Differential diagnosis of Mg deficiency in the ICU setting

Gastrointestinal disorders
Prolonged nasogastric suction
Malabsorption syndromes
Extensive bowel resection
Acute and chronic diarrhea
Intestinal and biliary fistulae
Protein-calorie malnutrition (parenteral nutrition, anorexia, refeeding
syndrome)
Acute hemorrhagic pancreatitis
Primary intestinal hypomagnesemia (neonatal)
Renal loss
Chronic parenteral fluid therapy
Osmotic diuresis (glucose, mannitol, urea)
Hypercalcemia
Alcohol
Drugs (see Table 2)
Metabolic acidosis (starvation, ketoacidosis, alcoholism)
Renal diseases
Chronic pyelonephritis, interstitial nephritis, and glomerulonephritis
Diuretic phase of acute tubular necrosis
Postobstructive nephropathy
Renal tubular acidosis
Post-renal transplantation
Primary renal hypomagnesemia


significant Mg depletion, such as vomiting and nasogastric suction, diarrhea, enteritis, inflammatory bowel disease, intestinal and biliary fistulas, intestinal surgery resections, and pancreatitis [41-44].

\section{Renal causes}

Many critically ill patients have hypomagnesemia caused by renal loss. The reabsorption of $\mathrm{Mg}^{2+}$ in the proximal tubule is proportional to tubular fluid flow and sodium reabsorption [17], and chronic parenteral fluid therapy, particularly with sodium-containing fluid, may therefore lead to Mg deficiency. The same mechanism may cause urinary wasting of $\mathrm{Mg}$ in osmotic diuresis. However, the most frequent cause of renal $\mathrm{Mg}$ wasting is medications, diuretics being particularly important [45]. Carbonic anhydrase inhibitors, osmotic agents, furosemide, bumetanide, and ethacrynic acid all increase $\mathrm{Mg}$ excretion [46], whereas the effect of thiazide diuretics on renal $\mathrm{Mg}$ handling is controversial [45]. Moreover, the aminoglycoside antibiotics [47], the chemotherapeutic agent cisplatin [48], and the immunosuppressive agent cyclosporine [49] are all reported to cause renal $\mathrm{Mg}$ wasting potentially causing $\mathrm{Mg}$ deficiency. Notably, patients in the ICU often receive several different combinations of intravenous medications and might have impaired drug elimination capacity due to reduced kidney and/or lived function which together with potential drug-drug interactions might influence $\mathrm{Mg}$ homeostasis. This aspect should be considered by physicians treating ICU patients. Table 2 gives an overview of the drugs that potentially cause hypomagnesemia and their underlying mechanisms. Finally, metabolic acidosis due to diabetic ketoacidosis, starvation, or alcoholism also causes renal $\mathrm{Mg}$ wasting.

\section{Biochemical and clinical manifestations of hypomagnesemia}

Hypomagnesaemia is often secondary to other disease processes or drugs and the features of the primary disease may mask the signs of an $\mathrm{Mg}$ deficiency. Thus, a high index of suspicion is warranted [50]. An overview of the biochemical and clinical manifestations of hypomagnesemia are given in Table 3.

\section{Biochemical manifestations of hypomagnesemia Hypokalemia}

Hypokalemia is common in patients with $\mathrm{Mg}$ deficiency and about half of the patients with clinically potassium deficiency also have Mg depletion [51]. However, patients with

Table 2 Drugs associated with Mg deficiency and hypomagnesemia

\begin{tabular}{|c|c|c|}
\hline Drugs & Mechanisms causing Mg deficiency & Ref \\
\hline & Renal loss & \\
\hline \multicolumn{3}{|l|}{ Diuretics } \\
\hline Loop & $\begin{array}{l}\text { Increased renal Mg excretion by affecting the transepithelial voltage and inhibiting passive } \\
\text { absorption. }\end{array}$ & [118] \\
\hline Thiazides & Enhance $\mathrm{Mg}$ entry into the cells in the distal convoluted tubule. & [118] \\
\hline \multicolumn{3}{|l|}{ Antimicrobial } \\
\hline $\begin{array}{l}\text { Amphotericin B } \\
\text { Aminoglycosides } \\
\text { Capreomycin } \\
\text { Pentamidine }\end{array}$ & $\begin{array}{l}\text { Renal urinary Mg wasting caused by nephrotoxins may be part of tubular necrosis and acute } \\
\text { renal failure. Notably, impairment in Mg reabsorption in the loop of Henle and distal tubules } \\
\text { may occur before the onset and may persist after the resolution of renal damage. }\end{array}$ & {$[19,47,119]$} \\
\hline \multicolumn{3}{|l|}{ Chemotherapy } \\
\hline Cisplatin & $\begin{array}{l}\text { Renal urinary Mg wasting caused by nephrotoxins may be part of tubular necrosis and acute } \\
\text { renal failure. Cisplatin treatment is also associated with lowered intestinal absorption }\end{array}$ & [120] \\
\hline \multicolumn{3}{|l|}{ Immunosuppressive } \\
\hline Calcineurin inhibitors & $\begin{array}{l}\text { Urinary Mg wasting due to a downregulation of the } \mathrm{Mg}^{2+} \text { transport proteins (TRPM6) in the } \\
\text { loop of Henle and distal convoluted tubules. }\end{array}$ & [121] \\
\hline \multicolumn{3}{|c|}{ Epidermal growth factor receptor inhibitors } \\
\hline \multirow{2}{*}{$\begin{array}{l}\text { Cetuximab } \\
\text { Panitumumab } \\
\text { Matuzumab }\end{array}$} & $\begin{array}{l}\text { Urinary Mg wasting due to a downregulation of the TRPM6 in the loop of Henle and distal } \\
\text { convoluted tubules. }\end{array}$ & {$[122,123]$} \\
\hline & Gastrointestinal loss & \\
\hline \multirow[t]{2}{*}{ Proton-pump inhibitor } & Impairing the intestinal Mg absorption by inhibiting Mg transporters (TRPM6 and TRPM7). & {$[124,125]$} \\
\hline & Miscellaneous & \\
\hline Foscarnet & $\begin{array}{l}\text { A general potent chelator of divalent cations which therefore has the potential to reduce } \\
\text { ionized levels of Mg. }\end{array}$ & [126] \\
\hline Cardiac glycosides & Mg deficiency is associated with cardiac glycosides. The exact mechanisms are not known. & {$[65]$} \\
\hline
\end{tabular}


Table 3 Clinical and biochemical effects of moderate to severe Mg deficiency and hypomagnesemia

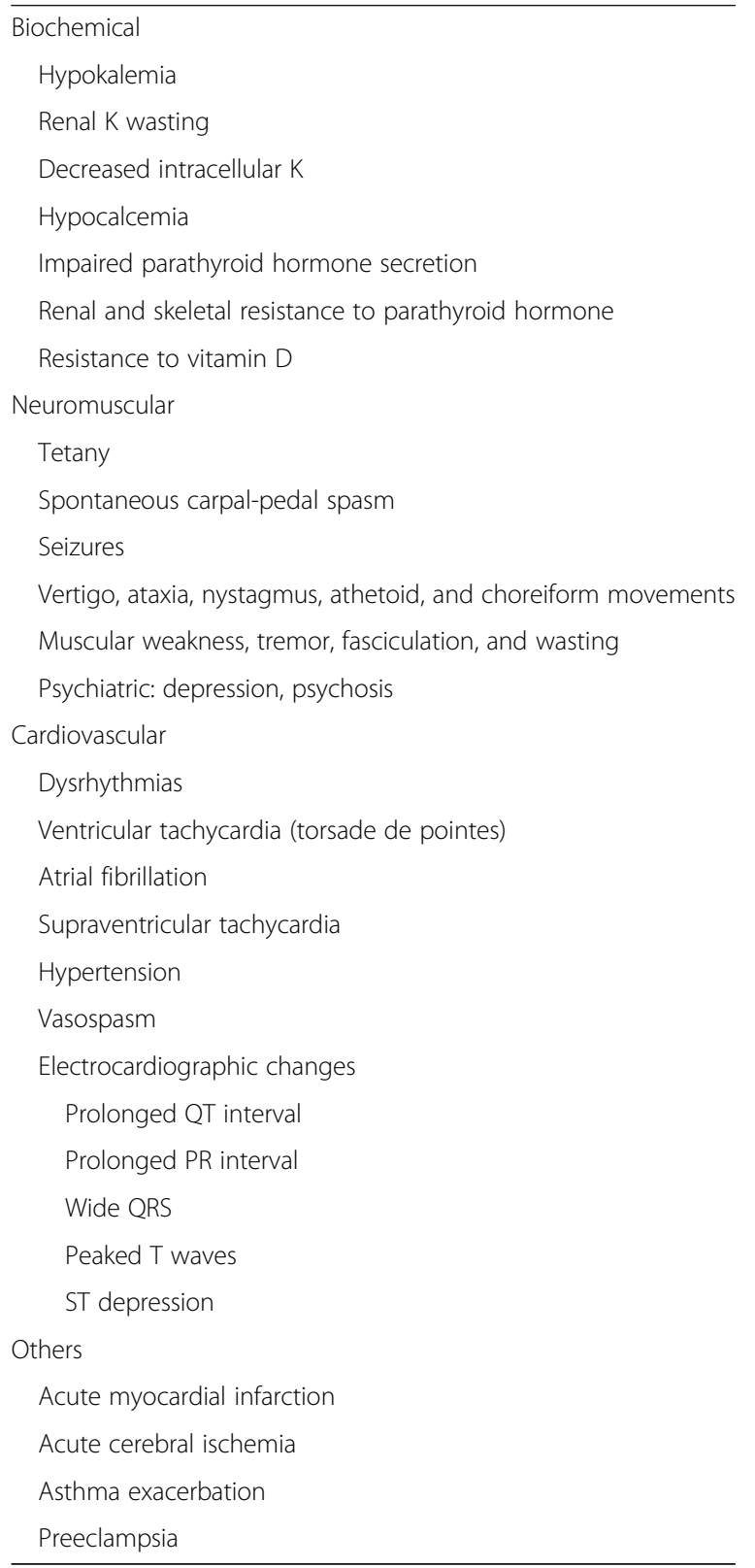

Mg depletion have a renal loss of potassium which is caused by an increased potassium secretion in the connecting tubule and the cortical collecting tubule. In the kidneys, $\mathrm{K}^{+}$is absorbed across the basolateral membrane via Na-KATPase and secreted into the lumen of the connecting tubule and cortical collecting tubule. This process is mediated by luminal potassium channels (ROMK). With a total lack of intracellular $\mathrm{Mg}^{2+}, \mathrm{K}^{+}$ions move freely through the ROMK channels. At physiologic intracellular $\mathrm{Mg}^{2+}$ concentration, ROMK conducts more $\mathrm{K}^{+}$ions inward than outward. Hypomagnesaemia is associated with reduction of intracellular $\mathrm{Mg}$, which in turn will release this inhibitory effect on potassium efflux. Due to the high concentration of potassium in the cell, this will promote potassium from the cell into the lumen which in turn leads to increased loss of potassium in the urine [52].

\section{Hypocalcemia}

Hypocalcemia is a well-known manifestation of Mg deficiency [53]. Patients with combined hypocalcemia and hypomagnesemia also show low levels of parathyroid hormone (PTH), and studies indicate that Mg deficiency inhibit the release of parathyroid hormone (PTH) in patients with coexisting hypocalcemia. Moreover, parenteral $\mathrm{Mg}$ stimulate PTH secretion [54, 55], and it is therefore suggested that reduced PTH secretion is a key contributor to hypocalcemia in $\mathrm{Mg}$ deficiency [55]. Animal studies have suggested that bone resistance to PTH contributes in hypocalcemia in $\mathrm{Mg}$ deficiency and studies in isolated perfused bone have revealed that $\mathrm{Mg}$ depletion reduces production of cyclic adenosine monophosphate (AMP) in bone with high levels of PTH [56]. Patients with $\mathrm{Mg}$ deficiency and hypocalcemia also present low levels of calcitriol (1.25-dihydroxyvitamin D) and together with impaired PTH secretion a reduced conversion of 25hydroxyvitamin $\mathrm{D}$ to 1.25-dihydroxyvitamin $\mathrm{D}$ in the kidneys is suspected [57].

\section{Clinical manifestations of hypomagnesemia Cardiovascular}

Mg has several effects on the cardiac conduction system. It is an essential cofactor of the Na-K-ATP pump which controls the movement of sodium and potassium across cell membranes [58]; Mg levels therefore influence myocardial excitability. Typical electrocardiogram changes and dysrhythmias are most common [59]. Widening of the QRS complex and peaking of $\mathrm{T}$ waves are described in moderate $\mathrm{Mg}$ deficiency whereas prolongation of the PR interval, progressive widening of the QRS complex, and diminution of the $\mathrm{T}$ wave are seen in severe $\mathrm{Mg}$ depletion [19]. Low serum $\mathrm{Mg}$ has been correlated to increased risk of atrial fibrillation (AF) after cardiac surgery, and also an association between serum $\mathrm{Mg}$ and development of AF in individuals without cardiovascular disease is described [59]. Ventricular premature complexes, polymorphic ventricular tachycardia, and ventricular fibrillation are more severe complications [60, 61], and these arrhythmias may be resistant to treatment [62]. Intracellular $\mathrm{Mg}$ depletion may be present even with normal serum Mg levels and must always be considered as a potential factor in arrhythmias. Other electrolyte disturbances such as potassium or calcium deficiency are often concurrent but not obligate [63, 64]. Notably, both cardiac glycosides such as digitalis and $\mathrm{Mg}$ deficiency 
inhibit Na-K-ATPase and their adaptive effect contributes to increased toxicity [65].

Patients with heart failure have an increased incidence of hypomagnesemia probably due to the use of diuretics (Table 2). Non-potassium-sparing diuretics reduce serum and total-body potassium and Mg. Low levels of $\mathrm{Mg}$ and potassium predispose for ventricular ectopic activity which is a predictor for arrhythmic death [66]. However, there is conflicting evidence regarding $\mathrm{Mg}$ levels and cardiovascular death in patients with heart failure. A large prospective study did not find $\mathrm{Mg}$ depletion as an independent risk factor for death [67] whereas an association between low levels of serum $\mathrm{Mg}$ and cardiovascular mortality has been reported by others [68]. Mg supplementation has previously been suggested for patients with heart failure $[69,70]$.

Postoperative atrial fibrillation following coronary bypass (CAPG) occurs in $10-65 \%$ of the patients [71]. Hypomagnesemia is common after cardiac surgery and $\mathrm{Mg}$ levels drop significantly and remain decreased for about $24 \mathrm{~h}$ postoperatively [72-74]. The exact mechanisms are not known but may be due to hemodilution and renal wasting. Citrate in predeposited autologous blood may also contribute to the decrease in the serum $\mathrm{Mg}$ concentration [74]. Postoperative hypomagnesemia is associated with a higher incidence of postoperative arrhythmias and low cardiac index [73]. A meta-analysis of seven double-blinded, placebo-controlled, randomized clinical trials demonstrated that intravenous Mg significantly reduced the incidence of postoperative atrial fibrillation [75]. Notably, severe complications such as hypotension, progressive respiratory failure, diminished deep tendon reflexes, complete heart block, and cardiac arrest have been reported in overdosing of $\mathrm{Mg}$ [76].

Recent studies investigating Mg therapy in acute myocardial infarction (AMI) indicate that low serum $\mathrm{Mg}$ levels increases the frequency of arrhythmias [77] and that intravenous $\mathrm{Mg}$ supplements reduce the frequency of ventricular arrhythmias in AMI [78]. Three large prospective studies have investigated the role of $\mathrm{Mg}$ after AMI. "The Leicester Intravenous Mg Intervention Trial (LIMIT-2)," from 1992, randomized 2316 patients with suspected AMI to receive $\mathrm{Mg}$ or placebo and found a $24 \%$ relative reduction in 28 -day mortality rate in patients receiving $\mathrm{Mg}$ therapy compared to the placebo group [79]. The Fourth International Study of Infarct Survival Trial (ISIS-4) randomized 58,050 participants in a $2 \times 2 \times 2$ factorial study. The treatment comparisons were captopril vs placebo, mononitrate vs placebo, and intravenous $\mathrm{Mg}$ vs placebo. There was no significant reduction in 5 weeks mortality [80]. The MAGIC trial was published in 2002 with the purpose to investigate early administration of intravenous $\mathrm{Mg}$ to high-risk patients with acute myocardial infarction. Over 6000 patients with ST-elevation myocardial infarction (STEMI) were randomized to receive intravenous $\mathrm{Mg}$ or placebo and the study found no effect of early administration of intravenous $\mathrm{Mg}$ on 30-day mortality [81]. One of the main criticisms against ISIS- 4 was the timing of the $\mathrm{Mg}$ administration as ISIS-4 randomized participants until $24 \mathrm{~h}$ after onset of symptoms whereas previously animal studies have stated that $\mathrm{Mg}$ must be given within $6 \mathrm{~h}$ after vessel occlusion [82, 83] for adequate effect. Moreover, $\mathrm{Mg}$ inhibits platelet activation by inhibiting Thromboxane A2 and interfering with the IIb-IIIa receptor complex [50], and $\mathrm{Mg}$ supplements are shown to inhibit plateletdependent thrombosis in patients with coronary artery disease [84]. Based on the above, there are no indications of $\mathrm{Mg}$ in AMI as a routine but it may be considered in selected situations [85].

\section{Neurovascular}

Animal models suggest a cerebroprotective effect of $\mathrm{Mg}$ [86] and $\mathrm{Mg}$ therapy given within $6 \mathrm{~h}$ of cerebral infarction probably reduce tissue damage [87]. Regarding human studies, the intravenous $\mathrm{Mg}$ efficacy in stroke trial (IMAGES) randomized 2589 patients to receive intravenous $\mathrm{Mg}$ or placebo within $12 \mathrm{~h}$ of stroke onset but this did not reduce mortality or disability [88]. Moreover, a study investigating administration of prehospital Mg sulfate in acute stroke (FAST-MAG) did not find reduction in disability at 90 days after disease onset [86]. Neither has intravenous $\mathrm{Mg}$ been found to improve clinical outcome in aneurysmal subarachnoid hemorrhages [89].

\section{Neuromuscular}

Neuromuscular hyperexitability is often the first clinical manifestation in patients with hypomagnesemia [90]. Concomitant $\mathrm{Mg}$ and calcium deficiency enhance neurological symptoms, but also patients with isolated $\mathrm{Mg}$ deficiency present neuromuscular hyperexitability [50]. Other neuromuscular symptoms are tetanus with positive Chvostek and Trousseau signs, muscle spasms, and cramps [19] which probably all are due to lowering of the threshold for nerve stimulation [91]. Hypomagnesaemia may also affect neurons in the brain and cause seizures, likely due to increased glutamate-activated depolarization. A decrease of extracellular $\mathrm{Mg}^{2+}$ allows a greater influx of calcium in the presynaptic nerves and releases a greater amount of neurotransmitters [92, 93]. Choreiform and athetoid movements, vertigo, apathy, delirium, and vertical nystagmus are also described [94]. Vertical nystagmus is a rare but may be a diagnostically and useful sign of severe hypomagnesaemia. In absence of structural lesions in the cerebellum or vestibular 
device, vertical vertigo is only associated with severe hypomagnesaemia or thiamine deficiency [95].

\section{Asthma}

$\mathrm{Mg}$ is established treatment of resistant asthma attacks [96, 97]. Mg increases the effect of salbutamol [98] through inhibiting $\mathrm{Ca}^{2+}$ influx by blocking the voltagedependent calcium channels which then relaxes the smooth muscle [28]. Mg also has an immunoregulatory effect by reducing pro-inflammatory mediators and promoting synthesis of prostacyclin and nitric oxide which stimulates broncho- and vasodilatation [99, 100]. Both intravenous and nebulized $\mathrm{Mg}$ has been used in treating acute asthma attacks. A review of 16 trials and 838 patients from 2012 showed that nebulized $\mathrm{MgSO}_{4}$ combined with a nebulized beta 2 agonist in adults did not provide a benefit in terms of lung function or need for hospitalization [101]. Another Cochrane review included 25 trials with a total of 2907 patients. The aim was to determine efficacy and safety of inhaled $\mathrm{MgSO}_{4}$ administered in acute asthma due to lung function and hospital admission. The authors' concluded with a modest additional benefit for the use of inhaled $\beta_{2}$-agonists and ipratropium bromide [102].

Several systematic reviews and meta-analyses have assessed the role of intravenous or nebulized $\mathrm{MgSO}_{4}$ in acute asthma. A large double-blinded, placebo-controlled trial from 2013 included 1109 participants randomized to receive intravenous $\mathrm{Mg}$, nebulized $\mathrm{Mg}$, or placebo. The aim was to determine whether intravenous or nebulized $\mathrm{MgSO}_{4}$ improve symptoms of breathlessness and reduce the need for hospital admission in adults with severe acute asthma. The authors concluded that nebulized $\mathrm{MgSO}_{4}$ has no role in the management of severe acute asthma in adults and suggested a limited role for intravenous $\mathrm{MgSO}_{4}$ [103]. Another review including 2313 patients from 14 studies concluded that a single infusion of $\mathrm{MgSO}_{4}$ reduced hospital admissions and improved lung function in adults with acute asthma who did not respond sufficiently to standard treatments [104]. Interestingly, low Mg intake has been associated with a higher prevalence of asthma [105].

\section{Preeclampsia}

Mg therapy has been used for decades as eclampsia prophylaxis. In 2002, the results from the "Magnesium Sulphate for Prevention of Eclampsia trial" (MAGPIE) were published. Ten thousand patients with preeclampsia were randomized to receive $\mathrm{Mg}$ therapy or placebo. The Mg therapy group showed significant fewer cases of eclampsia compared to the placebo group, maternal death was fewer among women who received $\mathrm{Mg}$ therapy, and Mg did not seem to give harmful side effects to either the mother or the fetus [106]. There are conflicting evidence regarding the correlation between $\mathrm{Mg}$ depletion and preeclampsia [107-109]. However, based on MAGPIE, it seems reasonably using $\mathrm{Mg}$ therapy in patients with preeclampsia although the cellular mechanisms remain to be fully understood.

\section{Magnesium therapy}

Because serum $\mathrm{Mg}$ not necessarily reflects the total body $\mathrm{Mg}$ status, patients at risk of magnesium deficiency or with symptoms consistent with hypomagnesaemia should be considered for treatment even with serum $\mathrm{Mg}$ within the normal range $[19,31]$. The magnitude of $\mathrm{Mg}$ deficiency is hard to predict but may be $1-2 \mathrm{mEq} / \mathrm{kg}$ of body weight [50]. In general, mild hypomagnesemia with no or only mild symptoms can be treated with per oral supplement [110] whereas parenteral $\mathrm{Mg}$ supplementation is indicated if $\mathrm{Mg}$ concentration is $<0.5 \mathrm{mmol} / \mathrm{L}$ or if the patient presents with significant symptoms. For critically ill patients with mild to moderate hypomagnesemia, empirically derived "rules of thumb" suggest that the administration of $1 \mathrm{~g}$ ( $8 \mathrm{mEq})$ of intravenous $\mathrm{Mg}$ will increase the serum $\mathrm{Mg}$ concentration by $0.15 \mathrm{mEq} / \mathrm{L}$ within 18 to $30 \mathrm{~h}$ [111]. However, current practice of $\mathrm{Mg}$ replacement therapy is mainly based upon acute myocardial infarction trials (Table 4) which suggest an initial bolus (e.g., $2 \mathrm{~g}(16 \mathrm{mEq}))$ followed by continuous infusions

Table 4 Continues Mg infusions over $24 \mathrm{~h}$

\begin{tabular}{|c|c|c|c|c|c|c|c|}
\hline Author & $N$ & Age, years & Male (\%) & $\begin{array}{l}\text { Serum creatinine } \\
(\mathrm{mg} / \mathrm{dL})\end{array}$ & Dose/diluent over $24 \mathrm{~h}$ & $\begin{array}{l}\text { Serum change } \\
(\mathrm{mEq} / \mathrm{L})\end{array}$ & $\begin{array}{l}\mathrm{mEq} / \mathrm{L} \\
\text { rise/g } \\
\mathrm{Mg} \text { given }\end{array}$ \\
\hline Shechter et al. [112] & 96 & 66 & 65 & $\leq 3$ & $\begin{array}{l}130 \mathrm{mEq} / 500 \mathrm{~mL} 5 \% \\
\text { dextrose in water }\end{array}$ & $1.65-2.82$ & 0.007 \\
\hline Raghu et al. [113] & 169 & 52.9 & 85 & $\leq 3$ & $\begin{array}{l}146 \mathrm{mEq} / 100 \mathrm{~mL} 0.9 \% \\
\mathrm{NaCl}\end{array}$ & $1.3-3.6$ & 0.11 \\
\hline Rasmussen et al. [114] & 56 & 64.6 & 70 & $\leq 3$ & $\begin{array}{l}100 \mathrm{mEq} / 1000 \mathrm{~mL} 5 \% \\
\text { dextrose in water }\end{array}$ & $1.5-2.46$ & 0.08 \\
\hline Woods et al. [79] & 1159 & 61.4 & 74 & $\leq 3.4$ & $\begin{array}{l}146 \mathrm{mEq} / 50 \mathrm{~mL} 0.9 \% \\
\mathrm{NaCl}\end{array}$ & $1.64-3.1$ & 0.08 \\
\hline
\end{tabular}


Table 5 Treatment with $\mathrm{Mg}$ in specific clinical settings

\begin{tabular}{|c|c|c|c|}
\hline Diagnose & Suggested Mg doses & Comments & Ref \\
\hline $\begin{array}{l}\text { Hemodynamically stable } \\
\text { patients with severe } \\
\text { symptomatic } \\
\text { hypomagnesemia }\end{array}$ & $\begin{array}{l}\text { 1-2 g [8-16 mEq] (4-8 mmol) MgSO4 given } \\
\text { initially over } 5-60 \text { min followed by an infusion } \\
4-8 \mathrm{~g} \text { [32-64 mEq] (16-32 mmol) given slowly } \\
\text { over } 12-24 \mathrm{~h} \text {. }\end{array}$ & - & {$[116,128]$} \\
\hline Torsades de pointes & $\begin{array}{l}2 \mathrm{~g} \text { [16 mEq] ( } 8 \text { mmol) over } 2-15 \mathrm{~min} \\
\text { followed by a continuous infusion. }\end{array}$ & $\begin{array}{l}\text { The rate of } \mathrm{Mg} \text { infusion depends on the clinical } \\
\text { situation. Rapid infusion is associated with } \\
\text { hypotension and asystole. }\end{array}$ & {$[116,117]$} \\
\hline Preeclampsia & $\begin{array}{l}4 \mathrm{~g} \text { [32 } \mathrm{mEq}](16 \mathrm{mmol}) \text { over } 10-15 \mathrm{~min} \\
\text { followed by } 1 \mathrm{~g} \text { [8 mEq] ( } 8 \mathrm{mmol} \text { ) every } \\
\text { following hours. }\end{array}$ & $\begin{array}{l}\text { Evidence is conflicting and no consensus about } \\
\text { the optimal Mg regimen exists. Suggested loading } \\
\text { doses vary from } 4 \text { to } 6 \mathrm{~g} \text { (32-48 mEq; } 16-24 \mathrm{mmol}) \\
\text { and maintenance doses of } 1-3 \mathrm{~g} \text { (8-24 mEq; 4-12 } \\
\mathrm{mmol} / \mathrm{h} \text {. }\end{array}$ & [106] \\
\hline
\end{tabular}

up to $16 \mathrm{~g}$ (130 $\mathrm{mEq})$ over $24 \mathrm{~h}$ [79, 112-114]. Severe hypomagnesemia may require treatment with doses until $1.5 \mathrm{mEq} / \mathrm{kg}$; doses < $6 \mathrm{~g} \mathrm{MgSO}_{4}$ can be given over a period of 8-12 h whereas higher doses should be administrated over a time period $>25 \mathrm{~h}$ [115]. The slow distribution of $\mathrm{Mg}$ in tissues and the rapidly renal excretion makes the infusion time crucial.

In the acute clinical settings with hemodynamically unstable patients, including patients with severe arrhythmias, established recommendations suggest giving $16 \mathrm{mEq}$ ( $8 \mathrm{mmol}$ ) of $\mathrm{Mg}$ over $2-15 \mathrm{~min}$ followed by a continuous infusion [116, 117]. In the MAGPIE study [106], $32 \mathrm{mEq}$ (4 g) Mg was initially given, followed by $8 \mathrm{mEq}(1 \mathrm{~g})$ per hour in women with preeclampsia [106]. Table 5 gives an overview of suggested $\mathrm{Mg}$ therapy in specific clinical setting. The evidence of using $\mathrm{Mg}$ as a routine in other critical conditions such as asthma or CAPG is still insufficient.

Patients with renal failure are at risk of developing hypermagnesemia and $\mathrm{Mg}$ treatment is therefore generally not recommended for these patients. However, $\mathrm{Mg}$ therapy should be considered in patients with moderately reduced glomerular filtration rate and severe $\mathrm{Mg}$ deficiency. The dose of $\mathrm{Mg}$ must be adjusted and patients should be carefully monitored both biochemically and clinically. High levels of $\mathrm{Mg}(>4-5 \mathrm{mmol} / \mathrm{L})$ may give muscle weakness, reduced respiration, and in worst case cardiac arrest. In case of intolerable intoxication; intravenous calcium (100-200 mg over 5-10 min) should be administrated as it antagonizes the neuromuscular and cardiovascular effects of $\mathrm{Mg}[50,115]$.

\section{Conclusion}

- Mg deficiency is common in critically ill patients, may cause potentially fatal complications, and associates with increased mortality.

- Mg deficiency in critically ill patients is mainly caused by gastrointestinal and/or renal disorders and may lead to secondary hypokalemia and hypocalcemia, and severe neuromuscular and cardiovascular clinical manifestations.

- Because of the physical distribution of $\mathrm{Mg}$, there are no readily or easy methods to assess $\mathrm{Mg}$ status. However, serum $\mathrm{Mg}$ and the $\mathrm{Mg}$ tolerance test are most widely used.

- Patients at risk of $\mathrm{Mg}$ deficiency, with typical biochemical findings or clinical symptoms of hypomagnesemia, should be considered for treatment even with serum $\mathrm{Mg}$ within the normal range.

- There are limited studies to guide intermittent therapy of $\mathrm{Mg}$ deficiency in critically ill patients but some empirical guidelines exist. Further clinical trials and critical evaluation of empiric $\mathrm{Mg}$ replacement strategies is needed.

Acknowledgements

We would like to thank Dr. Øystein Bruserud for his valuable contributions.

Funding

No funding.

Availability of data and materials

Not applicable.

Authors' contributions

$B A H$ and $\varnothing B$ did the literature search and wrote the manuscript together Both authors read and approved the final manuscript.

Ethics approval and consent to participate

No approval is required.

Consent for publication

No consent is required.

Competing interests

The authors declare that they have no competing interests.

\section{Publisher's Note}

Springer Nature remains neutral with regard to jurisdictional claims in published maps and institutional affiliations.

\section{Author details}

'Department of Microbiology, Førde Hospital, Førde, Norway. ${ }^{2}$ Section for Endocrinology, Department of Clinical Science, University of Bergen, Bergen, Norway. 


\section{Received: 8 February 2018 Accepted: 13 March 2018} Published online: 27 March 2018

\section{References}

1. Whang R, Oei TO, Aikawa JK, Watanabe A, Vannatta J, Fryer A, et al. Predictors of clinical hypomagnesemia. Hypokalemia, hypophosphatemia, hyponatremia, and hypocalcemia. Arch Intern Med. 1984;144:1794-6.

2. Wong ET, Rude RK, Singer FR, Shaw ST Jr. A high prevalence of hypomagnesemia and hypermagnesemia in hospitalized patients. Am J Clin Pathol. 1983;79:348-52

3. Hayes JP, Ryan MF, Brazil N, Riordan TO, Walsh JB, Coakley D. Serum hypomagnesaemia in an elderly day-hospital population. Ir Med J. 1989:82:117-9.

4. Reinhart RA, Desbiens NA. Hypomagnesemia in patients entering the ICU. Crit Care Med. 1985;13:506-7.

5. Ryzen E, Wagers PW, Singer FR, Rude RK. Magnesium deficiency in a medical ICU population. Crit Care Med. 1985;13:19-21.

6. Rubeiz GJ, Thill-Baharozian M, Hardie D, Carlson RW. Association of hypomagnesemia and mortality in acutely ill medical patients. Crit Care Med. 1993;21:203-9.

7. Soliman HM, Mercan D, Lobo SS, Melot C, Vincent JL. Development of ionized hypomagnesemia is associated with higher mortality rates. Crit Care Med. 2003:31:1082-7.

8. Fairley J, Glassford NJ, Zhang L, Bellomo R. Magnesium status and magnesium therapy in critically ill patients: a systematic review. J Crit Care. 2015;30:1349-58

9. Fairley JL, Zhang L, Glassford NJ, Bellomo R. Magnesium status and magnesium therapy in cardiac surgery: a systematic review and metaanalysis focusing on arrhythmia prevention. J Crit Care. 2017;42:69-77.

10. Jiang $P, L \vee Q, L a i T, X u F$. Does hypomagnesemia impact on the outcome of patients admitted to the intensive care unit? A systematic review and meta-analysis. Shock. 2017:47:288-95.

11. Elin RJ. Assessment of magnesium status. Clin Chem. 1987;33:1965-70.

12. Pham PC, Pham PA, Pham SV, Pham PT, Pham PM, Pham PT. Hypomagnesemia: a clinical perspective. Int J Nephrol Renovasc Dis 2014;7:219-30.

13. Quamme GA. Recent developments in intestinal magnesium absorption. Curr Opin Gastroenterol. 2008:24:230-5.

14. Fine KD, Santa Ana CA, Porter JL, Fordtran JS. Intestinal absorption of magnesium from food and supplements. J Clin Invest. 1991:88:396-402.

15. Schweigel M, Martens $H$. Magnesium transport in the gastrointestinal tract. Front Biosci. 2000:5:D666-77.

16. Sutton RA, Domrongkitchaiporn S. Abnormal renal magnesium handling. Miner Electrolyte Metab. 1993;19:232-40.

17. Quamme GA, de Rouffignac C. Epithelial magnesium transport and regulation by the kidney. Front Biosci. 2000;5:D694-711.

18. Cole DE, Quamme GA. Inherited disorders of renal magnesium handling. J Am Soc Nephrol. 2000;11:1937-47.

19. Agus ZS. Hypomagnesemia. J Am Soc Nephrol. 1999;10:1616-22.

20. Wacker WE, Parisi AF. Magnesium metabolism. N Engl J Med. 1968;278:772776 concl.

21. Hexum T, Samson FE Jr, Himes RH. Kinetic studies of membrane (Na+-K +-Mg2+)-ATPase. Biochim Biophys Acta. 1970;212:322-31.

22. Grubbs RD, Maguire ME. Magnesium as a regulatory cation: criteria and evaluation. Magnesium. 1987;6:113-27.

23. Johnson JD, Hand WL, King-Thompson NL. The role of divalent cations in interactions between lymphokines and macrophages. Cell Immunol. 1980; 53:236-45.

24. Chaigne-Delalande $B$, Lenardo MJ. Divalent cation signaling in immune cells. Trends Immunol. 2014;35:332-44.

25. Weglicki WB, Phillips TM. Pathobiology of magnesium deficiency: a cytokine/neurogenic inflammation hypothesis. Am J Phys. 1992;263:R734-7.

26. Weglicki WB, Phillips TM, Freedman AM, Cassidy MM, Dickens BF. Magnesium-deficiency elevates circulating levels of inflammatory cytokines and endothelin. Mol Cell Biochem. 1992;110:169-73.

27. Weglicki WB, Mak IT, Stafford RE, Dickens BF, Cassidy MM, Phillips TM. Neurogenic peptides and the cardiomyopathy of magnesium-deficiency: effects of substance P-receptor inhibition. Mol Cell Biochem. 1994;130:103-9.

28. Saris NE, Mervaala E, Karppanen H, Khawaja JA, Lewenstam A. Magnesium. An update on physiological, clinical and analytical aspects. Clin Chim Acta. 2000;294:1-26.
29. Jahnen-Dechent W, Ketteler M. Magnesium basics. Clin Kidney J. 2012; 5:i3-i14.

30. Swaminathan R. Magnesium metabolism and its disorders. Clin Biochem Rev. 2003;24:47-66.

31. Ryzen E, Elbaum N, Singer FR, Rude RK. Parenteral magnesium tolerance testing in the evaluation of magnesium deficiency. Magnesium. 1985:4:137-47.

32. Quamme GA. Laboratory evaluation of magnesium status. Renal function and free intracellular magnesium concentration. Clin Lab Med. 1993;13:209-23.

33. Koch SM, Warters RD, Mehlhorn U. The simultaneous measurement of ionized and total calcium and ionized and total magnesium in intensive care unit patients. J Crit Care. 2002;17:203-5.

34. Sanders GT, Huijgen HJ, Sanders R. Magnesium in disease: a review with special emphasis on the serum ionized magnesium. Clin Chem Lab Med. 1999;37:1011-33.

35. Lanzinger MJ, Moretti EW, Wilderman RF, El-Moalem HE, Toffaletti JG, Moon RE. The relationship between ionized and total serum magnesium concentrations during abdominal surgery. J Clin Anesth. 2003:15:245-9.

36. Fiser RT, Torres A Jr, Butch AW, Valentine JL. lonized magnesium concentrations in critically ill children. Crit Care Med. 1998;26:2048-52.

37. Huijgen HJ, Soesan M, Sanders R, Mairuhu WM, Kesecioglu J, Sanders GT. Magnesium levels in critically ill patients. What should we measure? Am J Clin Pathol. 2000;114:688-95.

38. Elming $H$, Seibaek M, Ottesen MM, Torp-Pedersen C, Holm E, Thode J, et al. Serum-ionised magnesium in patients with acute myocardial infarction. Relation to cardiac arrhythmias, left ventricular function and mortality. Magnes Res. 2000;13:285-92.

39. Wilkes NJ, Mallett SV, Peachey T, Di Salvo C, Walesby R. Correction of ionized plasma magnesium during cardiopulmonary bypass reduces the risk of postoperative cardiac arrhythmia. Anesth Analg. 2002;95:828-834, table of contents.

40. Yeh DD, Chokengarmwong N, Chang Y, Yu L, Arsenault C, Rudolf J, et al. Total and ionized magnesium testing in the surgical intensive care unit-opportunities for improved laboratory and pharmacy utilization. J Crit Care. 2017;42:147-51.

41. LaSala MA, Lifshitz F, Silverberg M, Wapnir RA, Carrera E. Magnesium metabolism studies in children with chronic inflammatory disease of the bowel. J Pediatr Gastroenterol Nutr. 1985:4:75-81.

42. Nyhlin H, Dyckner T, Ek B, Wester PO. Plasma and skeletal muscle electrolytes in patients with Crohn's disease. J Am Coll Nutr. 1985:4:531-8.

43. Hanna S. Plasma magnesium in health and disease. J Clin Pathol. 1961; 14:410-4

44. Smith GA, Tompkins RK. Biliary magnesium loss in the postoperative patient. Arch Surg. 1974;109:77-9.

45. Ryan MP. Diuretics and potassium/magnesium depletion. Directions for treatment. Am J Med. 1987:82:38-47.

46. Quamme GA, Dirks JH. The physiology of renal magnesium handling. Ren Physiol. 1986;9:257-69.

47. Alexandridis $\mathrm{G}$, Liberopoulos E, Elisaf M. Aminoglycoside-induced reversible tubular dysfunction. Pharmacology. 2003;67:118-20.

48. Buckley JE, Clark VL, Meyer TJ, Pearlman NW. Hypomagnesemia after cisplatin combination chemotherapy. Arch Intern Med. 1984;144:2347-8.

49. Thompson $\mathrm{CB}$, June $\mathrm{CH}$, Sullivan KM, Thomas ED. Association between cyclosporin neurotoxicity and hypomagnesaemia. Lancet. 1984;2:1116-20.

50. Tong GM, Rude RK. Magnesium deficiency in critical illness. J Intensive Care Med. 2005;20:3-17.

51. Whang $R$, Whang $D D$, Ryan MP. Refractory potassium repletion. A consequence of magnesium deficiency. Arch Intern Med. 1992;152:40-5.

52. Huang $\mathrm{CL}$, Kuo E. Mechanism of hypokalemia in magnesium deficiency. J Am Soc Nephrol. 2007;18:2649-52.

53. Griffin TP, Murphy M, Coulter J, Murphy MS. Symptomatic hypocalcaemia secondary to PTH resistance associated with hypomagnesaemia after elective embolisation of uterine fibroid. BMJ Case Rep. 2013;2013. https://doi.org/10. 1136/bcr-2013-008708

54. Chase LR, Slatopolsky E. Secretion and metabolic efficacy of parthyroid hormone in patients with severe hypomagnesemia. J Clin Endocrinol Metab. 1974;38:363-71

55. Rude RK, Oldham SB, Singer FR. Functional hypoparathyroidism and parathyroid hormone end-organ resistance in human magnesium deficiency. Clin Endocrinol. 1976:5:209-24.

56. Freitag JJ, Martin KJ, Conrades MB, Bellorin-Font E, Teitelbaum S, Klahr S, et al. Evidence for skeletal resistance to parathyroid hormone in magnesium deficiency. Studies in isolated perfused bone. J Clin Invest. 1979;64:1238-44. 
57. Rude RK, Adams JS, Ryzen E, Endres DB, Niimi H, Horst RL, et al. Low serum concentrations of 1,25-dihydroxyvitamin $\mathrm{D}$ in human magnesium deficiency. J Clin Endocrinol Metab. 1985;61:933-40.

58. Skou JC, Butler KW, Hansen O. The effect of magnesium, ATP, P i, and sodium on the inhibition of the $(\mathrm{Na}++\mathrm{K}+)$-activated enzyme system by g-strophanthin. Biochim Biophys Acta. 1971;241:443-61.

59. Khan AM, Lubitz SA, Sullivan LM, Sun JX, Levy D, Vasan RS, et al. Low serum magnesium and the development of atrial fibrillation in the community: the Framingham Heart Study. Circulation. 2013;127:33-8.

60. Sueta CA, Clarke SW, Dunlap SH, Jensen L, Blauwet MB, Koch G, et al. Effect of acute magnesium administration on the frequency of ventricular arrhythmia in patients with heart failure. Circulation. 1994;89:660-6.

61. Tsuji H, Venditti FJ Jr, Evans JC, Larson MG, Levy D. The associations of levels of serum potassium and magnesium with ventricular premature complexes (the Framingham Heart Study). Am J Cardiol. 1994;74:232-5.

62. Kasaoka S, Tsuruta R, Nakashima K, Soejima Y, Miura T, Sadamitsu D, et al. Effect of intravenous magnesium sulfate on cardiac arrhythmias in critically ill patients with low serum ionized magnesium. Jpn Circ J. 1996;60:871-5.

63. Panahi Y, Mojtahedzadeh M, Najafi A, Ghaini MR, Abdollahi M, Sharifzadeh $M$, et al. The role of magnesium sulfate in the intensive care unit. EXCLI J. 2017:16:464-82

64. Banai S, Tzivoni D. Drug therapy for torsade de pointes. J Cardiovasc Electrophysiol. 1993:4:206-10.

65. Young IS, Goh EM, McKillop UH, Stanford CF, Nicholls DP, Trimble ER. Magnesium status and digoxin toxicity. Br J Clin Pharmacol. 1991;32:717-21.

66. Cooper HA, Dries DL, Davis CE, Shen YL, Domanski MJ. Diuretics and risk of arrhythmic death in patients with left ventricular dysfunction. Circulation. 1999;100:1311-5.

67. Eichhorn EJ, Tandon PK, DiBianco R, Timmis GC, Fenster PE, Shannon J, et al. Clinical and prognostic significance of serum magnesium concentration in patients with severe chronic congestive heart failure: the PROMISE study. Am Coll Cardiol. 1993;21:634-40.

68. Adamopoulos C, Pitt B, Sui X, Love TE, Zannad F, Ahmed A. Low serum magnesium and cardiovascular mortality in chronic heart failure: a propensity-matched study. Int J Cardiol. 2009;136:270-7.

69. Ceremuzynski L, Gebalska J, Wolk R, Makowska E. Hypomagnesemia in heart failure with ventricular arrhythmias. Beneficial effects of magnesium supplementation. J Intern Med. 2000;247:78-86.

70. Fuentes JC, Salmon AA, Silver MA. Acute and chronic oral magnesium supplementation: effects on endothelial function, exercise capacity, and quality of life in patients with symptomatic heart failure. Congest Heart Fail. 2006;12:9-13.

71. Maisel WH, Rawn JD, Stevenson WG. Atrial fibrillation after cardiac surgery. Ann Intern Med. 2001;135:1061-73.

72. Aglio LS, Stanford GG, Maddi R, Boyd JL 3rd, Nussbaum S, Chernow B. Hypomagnesemia is common following cardiac surgery. J Cardiothorac Vasc Anesth. 1991;5:201-8.

73. Parra L, Fita G, Gomar C, Rovira I, Marin JL. Plasma magnesium in patients submitted to cardiac surgery and its influence on perioperative morbidity. J Cardiovasc Surg. 2001;42:37-42.

74. Inoue S, Akazawa S, Nakaigawa Y, Shimizu R, Seo N. Changes in plasma total and ionized magnesium concentrations and factors affecting magnesium concentrations during cardiac surgery. J Anesth. 2004;18:216-9.

75. Gu WJ, Wu ZJ, Wang PF, Aung LH, Yin RX. Intravenous magnesium prevents atrial fibrillation after coronary artery bypass grafting: a meta-analysis of 7 double-blind, placebo-controlled, randomized clinical trials. Trials. 2012;13:41.

76. Cavell GF, Bryant C, Jheeta S. latrogenic magnesium toxicity following intravenous infusion of magnesium sulfate: risks and strategies for prevention. BMJ Case Rep. 2015;2015. https://doi.org/10.1136/bcr-2015209499.

77. Dyckner T. Serum magnesium in acute myocardial infarction. Relation to arrhythmias. Acta Med Scand. 1980;207:59-66.

78. Rasmussen HS, Suenson M, McNair P, Norregard P, Balslev S. Magnesium infusion reduces the incidence of arrhythmias in acute myocardial infarction. A double-blind placebo-controlled study. Clin Cardiol. 1987;10:351-6.

79. Woods KL, Fletcher S, Roffe C, Haider Y. Intravenous magnesium sulphate in suspected acute myocardial infarction: results of the second Leicester Intravenous Magnesium Intervention Trial (LIMIT-2). Lancet. 1992;339:1553-8.

80. ISIS-4 Collaborative Group. ISIS-4: a randomised factorial trial assessing early oral captopril, oral mononitrate, and intravenous magnesium sulphate in 58,050 patients with suspected acute myocardial infarction. ISIS-4 (Fourth
International Study of Infarct Survival) collaborative group. Lancet. 1995;345: 669-85.

81. Antman EM. The Magnesium in Coronaries (MAGIC) Trial Investigators. Early administration of intravenous magnesium to high-risk patients with acute myocardial infarction in the magnesium in coronaries (MAGIC) trial: a randomised controlled trial. Lancet. 2002;360:1189-96.

82. Woods KL, Abrams K. The importance of effect mechanism in the design and interpretation of clinical trials: the role of magnesium in acute myocardial infarction. Prog Cardiovasc Dis. 2002;44:267-74.

83. Vassalle C, Battaglia D, Vannucci A, Chatzianagnostou K, Landi P, Arvia C, et al. Low magnesium is not a significant predictor of hard events in acute myocardial infarction. BBA Clin. 2016;5:130-3.

84. Shechter M, Merz CN, Paul-Labrador M, Meisel SR, Rude RK, Molloy MD et al. Oral magnesium supplementation inhibits platelet-dependent thrombosis in patients with coronary artery disease. Am J Cardiol. 1999; 84:152-6

85. Shechter M. Magnesium and cardiovascular system. Magnes Res. 2010; 23:60-72

86. Saver JL, Starkman S, Eckstein M, Stratton SJ, Pratt FD, Hamilton S, et al. Prehospital use of magnesium sulfate as neuroprotection in acute stroke. $\mathrm{N}$ Engl J Med. 2015;372:528-36.

87. Muir KW. Magnesium for neuroprotection in ischaemic stroke: rationale for use and evidence of effectiveness. CNS Drugs. 2001;15:921-30.

88. Muir KW, Lees KR, Ford I, Davis S. Magnesium for acute stroke (Intravenous Magnesium Efficacy in Stroke trial): randomised controlled trial. Lancet. 2004;363:439-45.

89. Dorhout Mees SM, Algra A, Vandertop WP, van Kooten F, Kuijsten HA, Boiten J, et al. Magnesium for aneurysmal subarachnoid haemorrhage (MASH-2): a randomised placebo-controlled trial. Lancet. 2012;380:44-9.

90. Nadler JL, Rude RK. Disorders of magnesium metabolism. Endocrinol Metab Clin N Am. 1995;24:623-41

91. Frankenhaeuser $\mathrm{B}$, Meves $\mathrm{H}$. The effect of magnesium and calcium on the frog myelinated nerve fibre. J Physiol. 1958;142:360-5.

92. Mody I, Lambert JD, Heinemann U. Low extracellular magnesium induces epileptiform activity and spreading depression in rat hippocampal slices. J Neurophysiol. 1987:57:869-88.

93. Augustine GJ, Charlton MP, Smith SJ. Calcium action in synaptic transmitter release. Annu Rev Neurosci. 1987;10:633-93.

94. Flink EB. Magnesium deficiency. Etiology and clinical spectrum. Acta Med Scand Suppl. 1981;647:125-37.

95. Saul RF, Selhorst JB. Downbeat nystagmus with magnesium depletion. Arch Neurol. 1981;38:650-2

96. Bateman ED, Hurd SS, Barnes PJ, Bousquet J, Drazen JM, FitzGerald M, et al. Global strategy for asthma management and prevention: GINA executive summary. Eur Respir J. 2008;31:143-78.

97. British Thoracic Society, Scottish Intercollegiate Guidelines Network. British guideline on the management of asthma. Thorax. 2014;69(Suppl 1):1-192.

98. Turner DL, Ford WR, Kidd EJ, Broadley KJ, Powell C. Effects of nebulised magnesium sulphate on inflammation and function of the guinea-pig airway. Eur J Pharmacol. 2017;801:79-85.

99. Del Castillo J, Engbaek L. The nature of the neuromuscular block produced by magnesium. J Physiol. 1954;124:370-84.

100. Kemp PA, Gardiner SM, March JE, Bennett T, Rubin PC. Effects of NG-nitro-Larginine methyl ester on regional haemodynamic responses to $\mathrm{MgSO} 4$ in conscious rats. Br J Pharmacol. 1994;111:325-31.

101. Powel C. Cochrane database of systematic reviews 2012.

102. Knightly R. Cochrane database of systematic reviews 2017.

103. Goodacre S, Cohen J, Bradburn M, Gray A, Benger J, Coats T. Intravenous or nebulised magnesium sulphate versus standard therapy for severe acute asthma (3Mg trial): a double-blind, randomised controlled trial. Lancet Respir Med. 2013;1:293-300.

104. Kew K. Cochrane database of systematic reviews 2014.

105. Britton J, Pavord I, Richards K, Wisniewski A, Knox A, Lewis S, et al. Dietary magnesium, lung function, wheezing, and airway hyperreactivity in a random adult population sample. Lancet. 1994;344:357-62.

106. Altman D, Carroli G, Duley L, Farrell B, Moodley J, Neilson J, et al. Do women with pre-eclampsia, and their babies, benefit from magnesium sulphate? The Magpie trial: a randomised placebo-controlled trial. Lancet. 2002;359:1877-90

107. Standley CA, Whitty JE, Mason BA, Cotton DB. Serum ionized magnesium levels in normal and preeclamptic gestation. Obstet Gynecol. 1997:89:24-7. 
108. Handwerker SM, Altura BT, Altura BM. lonized serum magnesium and potassium levels in pregnant women with preeclampsia and eclampsia. J Reprod Med. 1995;40:201-8.

109. Frenkel Y, Weiss M, Shefi M, Lusky A, Mashiach S, Dolev E. Mononuclear cell magnesium content remains unchanged in various hypertensive disorders of pregnancy. Gynecol Obstet Investig. 1994;38:220-2.

110. Yamamoto M, Yamaguchi T. Causes and treatment of hypomagnesemia. Clin Calcium. 2007;17:1241-8.

111. Hammond DA, Stojakovic J, Kathe N, Tran J, Clem OA, Erbach K, et al. Effectiveness and safety of magnesium replacement in critically ill patients admitted to the medical intensive care unit in an academic medical center: a retrospective, cohort study. J Intensive Care Med 2017.doi: https://doi.org/ 10.1177/0885066617720631.

112. Shechter M, Hod H, Chouraqui P, Kaplinsky E, Rabinowitz B. Magnesium therapy in acute myocardial infarction when patients are not candidates for thrombolytic therapy. Am J Cardiol. 1995;75:321-3.

113. Raghu C, Peddeswara Rao P, Seshagiri Rao D. Protective effect of intravenous magnesium in acute myocardial infarction following thrombolytic therapy. Int J Cardiol. 1999;71:209-15.

114. Rasmussen HS, McNair P, Norregard P, Backer V, Lindeneg O, Balslev S. Intravenous magnesium in acute myocardial infarction. Lancet. 1986;1:234-6.

115. Velissaris D, Karamouzos V, Pierrakos C, Aretha D, Karanikolas M. Hypomagnesemia in critically ill sepsis patients. J Clin Med Res. 2015;7:911-8.

116. Neumar RW, Otto CW, Link MS, Kronick SL, Shuster M, Callaway CW, et al. Part 8: adult advanced cardiovascular life support: 2010 American Heart Association guidelines for cardiopulmonary resuscitation and emergency cardiovascular care. Circulation. 2010;122:S729-67.

117. Tzivoni D, Banai S, Schuger C, Benhorin J, Keren A, Gottlieb S, et al. Treatment of torsade de pointes with magnesium sulfate. Circulation. 1988;77:392-7.

118. Quamme GA. Renal magnesium handling: new insights in understanding old problems. Kidney Int. 1997:52:1180-95.

119. Shah GM, Kirschenbaum MA. Renal magnesium wasting associated with therapeutic agents. Miner Electrolyte Metab. 1991;17:58-64.

120. Lajer H, Kristensen M, Hansen HH, Christensen S, Jonassen T, Daugaard G. Magnesium and potassium homeostasis during cisplatin treatment. Cancer Chemother Pharmacol. 2005;55:231-6.

121. Nijenhuis T, Hoenderop JG, Bindels RJ. Downregulation of $\mathrm{Ca}(2+)$ and $\mathrm{Mg}(2+)$ transport proteins in the kidney explains tacrolimus (FK506)-induced hypercalciuria and hypomagnesemia. J Am Soc Nephrol. 2004;15:549-57.

122. Schrag D, Chung KY, Flombaum C, Saltz L. Cetuximab therapy and symptomatic hypomagnesemia. J Natl Cancer Inst. 2005;97:1221-4.

123. Groenestege WM, Thebault S, van der Wijst J, van den Berg D, Janssen R, Tejpar S, et al. Impaired basolateral sorting of pro-EGF causes isolated recessive renal hypomagnesemia. J Clin Invest. 2007;117:2260-7.

124. Vichot AA, Geller DS, Perazella MA. Progression of polycystic kidney disease in a kidney transplant. Kidney Int. 2013:83:533.

125. Hansen B, Bruserud $\varnothing$. Hypomagnesemia as a potentially life-threatening adverse effect of pantoprazole. Oxf Med Case Reports. 2016;2016(7):147-9.

126. Huycke MM, Naguib MT, Stroemmel MM, Blick K, Monti K, Martin-Munley S, et al. A double-blind placebo-controlled crossover trial of intravenous magnesium sulfate for foscarnet-induced ionized hypocalcemia and hypomagnesemia in patients with AIDS and cytomegalovirus infection. Antimicrob Agents Chemother. 2000;44:2143-8.

127. Ryman KM, Canada TW. Deficiencies of magnesium replacement in the critically ill. J Intensive Care Med 2017.doi: https://doi.org/10.1177/ 0885066617735784.

128. Kraft MD, Btaiche IF, Sacks GS, Kudsk KA. Treatment of electrolyte disorders in adult patients in the intensive care unit. Am J Health Syst Pharm. 2005;62: 1663-82.

\section{Submit your next manuscript to BioMed Central and we will help you at every step:}

- We accept pre-submission inquiries

- Our selector tool helps you to find the most relevant journal

- We provide round the clock customer support

- Convenient online submission

- Thorough peer review

- Inclusion in PubMed and all major indexing services

- Maximum visibility for your research

Submit your manuscript at www.biomedcentral.com/submit 